\title{
The New Transatlantic Partnership
}

In February 2019, speaking at the annual Munich Security Conference, former Vice President Joe Biden promised that "America will be back" when Donald Trump's term comes to an end. His speech was met with a standing ovation, exposing an open secret: The state of the transatlantic alliance is in disarray. This month, Biden once again took the world stage, this time as the newly elected US President. But the return of a familiar face and respected ally does not mean a return to the old status quo. In the last four years, the Trump administration has altered the course of the liberal international order with its promise of "America First". Trump's counterstance to the previous administration's policies on the environment, defence, trade, freedom of the press and foreign affairs has weakened the state of Western diplomacy. President Biden is expected to mend many of the divisions that have formed as of late. But Europe would be wise to acknowledge that the world looks very different now than it did four years ago and to navigate a new transatlantic partnership accordingly.

EU-US Relations: Reinventing the Transatlantic Agenda

Steven Blockmans, Centre for European Policy Studies, Brussels, Belgium; and University of Amsterdam, Netherlands.

Taming the Chinese Dragon: A Promising Cornerstone for Transatlantic Trade Cooperation?

Simon J. Evenett, University of St. Gallen, Switzerland; and Centre for Economic Policy Research, London, UK.

Biden's Security Policy: Democratic Security or Democratic Exceptionalism?

Simona R. Soare, European Union Institute for Security Studies, Paris, France.

\section{A Real Chance for the Transatlantic Partnership on Climate Policy \\ Claudia Kemfert, German Institute for Economic Research (DIW Berlin); Leuphana University Lüneburg, Germany.}

Transatlantic Trade Dispute: Solution for Airbus-Boeing Under Biden?

Stephan Wittig, University of Hamburg, Germany. 